\begin{tabular}{|l|l|l||}
\hline \multicolumn{2}{|c|}{ PublisherInfo } \\
\hline \hline PublisherName & $:$ & BioMed Central \\
\hline \hline PublisherLocation & $:$ & London \\
\hline \hline PublisherImprintName & $:$ & BioMed Central \\
\hline \hline
\end{tabular}

\title{
Rapid SNP scanning
}

\begin{tabular}{|l|l|l||}
\hline \multicolumn{2}{|c|}{ ArticleInfo } \\
\hline \hline ArticleID & $:$ & 3954 \\
\hline \hline ArticleDOI & $:$ & $10.1186 /$ gb-spotlight-20010112-03 \\
\hline \hline ArticleCitationID & $:$ & spotlight-20010112-03 \\
\hline \hline ArticleSequenceNumber & $:$ & 25 \\
\hline \hline ArticleCategory & $:$ & Research news \\
\hline ArticleFirstPage & $:$ & 1 \\
\hline \hline ArticleLastPage & $:$ & 2 \\
\hline \hline & & RegistrationDate : 2001-01-12 \\
ArticleHistory & $:$ & OnlineDate \\
\hline \hline ArticleCopyright & $:$ & BioMed Central Ltd2001-01-12 \\
\hline \hline ArticleGrants & $:$ & \\
\hline \hline ArticleContext & $:$ & 130592211 \\
\hline \hline
\end{tabular}


William Wells

Email:wells@biotext.com

Single nucleotide polymorphisms (SNPs) are pouring into public databases, but methods for analyzing large numbers of SNPs in population studies lag behind. In the January 16 Proceedings of the National Academy of Sciences, Buetow et al. report that mass spectrometry (MS) and pooling of DNA samples can be combined to yield a rapid SNP genotyping method (Proc Natl Acad Sci USA 2001, 98:581-584). Buetow et al. define candidate SNPs as those sequences that show variation in multiple sequencing runs performed at Washington University (St Louis). DNA from 94 individuals is pooled, and candidate variable regions PCR-amplified. Low nanoliter aliquots are then transferred onto individual $200 \mu \mathrm{m}$ elements of a 96-element silicon chip. This is the substrate for matrix-assisted laser desorption/ionization time-of-flight (MALDI-TOF) MS. Less than four weeks of work confirms the polymorphism of, and yields accurate allele frequencies for, 3,646 SNPs. This is not yet enough for genome-wide studies of linkage disequilibrium, but suggests that an affordable system for carrying out such studies is not far off.

\section{References}

1. Large-scale identification, mapping, and genotyping of single-nucleotide polymorphisms in the human genome.

2. A Database of Single Nucleotide Polymorphisms, [http://www.ncbi.nlm.nih.gov/SNP/]

3. Proceedings of the National Academy of Sciences, [http://www.pnas.org/]

4. The CGAP Genetic Annotation Initiative, [http://cgap.nci.nih.gov/GAI]

5. Human EST Project, [http://genome.wustl.edu/est/esthmpg.html]

6. Centre d'etude du polymorphisme humain (CEPH): collaborative genetic mapping of the human genome.

This PDF file was created after publication. 